\title{
ДЕРЖАВОТВОРЧИЙ НАРАТИВ У ПРЕСОВОМУ ДИСКУРСІ ОСИПА ТУРЯНСЬКОГО
}

\author{
Андрій Печарський \\ Львівський національний університет імені Івана Франка \\ вул. Університетська, 1, 79000 Львів, Украӥна \\ e-mail:pecharskyy@ukr.net \\ https://orcid.org/0000-0003-4154-8956
}

Статтю присвячено типологічній характеристиці журналістської та літературної спадщини О. Турянського крізь призму українського державотворчого наративу. Увагу зосереджено на етнопсихологічній проблематиці українського народу стосовно його трагічної доленосної розбудови національної держави. У цьому аспекті О. Турянський притримувався власної концепції так званого «українського дводушшя», суть якої полягає в тому, що у внутрішніх порухах серця нашої нації живе дві душі: героя та раба. Відтак О. Турянський вважав основною доленосною причиною бездержавності українського народу його надмірний індивідуалізм, домінування емоційно-вольових чинників над раціональними та ненависть до влади як такої, що суперечить логіці державотворчих процесів.

Ключові слова: етнопсихологічний аспект, державотворчий наратив, «українське дводушшя», надмірний індивідуалізм, егоцентризм.

Постановка проблеми. Державотворчий наратив у пресовому дискурсі О. Турянського і сьогодні актуальний. Адже чимало подій, які зараз відбуваються на політичній арені України та за їі межами, є небезпечними для збереження і розвитку нашої національної держави. Серед цих чинників виокремлюються й особливості психічного складу етносу, на які звертав увагу О. Турянський у свойй журналістській та літературній творчості. Мета і завдання статті - здійснити типологічну характеристику журналістської та літературної спадщини О. Турянського крізь призму українського державотворчого наративу, а також обгрунтувати його етнопсихологічну проблематику.

Аналіз останніх досліджень та публікацій. Специфіка кореспондентської та літературної діяльності О. Турянського - це «біла пляма» в історії української журналістики міжвоєнного періоду 1918-1939 років. Однак схожу проблематику у наукових дослідженнях порушували такі літературознавці, письменники та журналісти: Т. Прохасько («Перша світова війна в українській класичній літературі: О. Турянський») $)^{1}$ Т. Дзись («Літературний контекст у проекції типології та сприймання: Йо-

\footnotetext{
1 Прохасько, Т. (2019), Перша світова війна в українській класичній літературі: О. Турянський. Лекція. URL: https://culturalproject.org/lectures/55ad008787cb94c0378b47d4

(C) Печарський А., 2020
} 
зеф Рот, Осип Турянський, Іван Франко»)2, Н. Мафтин («Поетика експресіонізму в романі Осипа Турянського «Поза межами болю» та повісті Леоніда Андреєва «Червоний сміх») ${ }^{3}$, М. Моклиця («Алегоричний код літератури, або Реабілітація алегорії триває») ${ }^{4}$, М. Нестелєєв («Поза межами й у межах: Осип Турянський і його найвідоміший твір») $)^{5}$ та ін.

Методологічна основа дослідження. У статті взято за основу культурно-історичний та етнопсихологічний методи наукового аналізу й синтезу, зокрема застосовано праці відомих українських науковців, політиків і громадських діячів: Д. Донцова, В. Липинського, Ю. Липи, Д. Віконської, В. Яніва та ін.

Виклад основного матеріалу. Коли на шпальтах українських чи зарубіжних ЗМІ з'являється ім'я О. Турянського, то в уяві реципієнта він постає передусім як автор знаменитого роману «Поза межами болю», який вважається одним із кращих художніх творів про Першу світову війну.

Осип Турянський, як митець і водночас журналіст, був 3 тієї когорти творців, що «призначені самим письменницьким інстинком, - як писав Ян Парандовський, вибирають перо серед декількох можливих засобів діяльності і, якщо воно було для них єдиною можливістю, відкладають його, як тільки виконають свою місію» ${ }^{6}$.

Здається, все ясно і просто, все народжується і вмирає. Проте О. Турянський не хотів миритися з таким жеребом долі. I після написання ліричного роману «Поза межами болю» (1921) - унікального, новаторського явища в європейській літературі, тішив себе надією, оптимізмом щодо такого визнання й своєї подальшої творчості (алегоричний твір «Дума пралісу», повість «Син землі», оповідання «Боротьба за великість», комедія «Раби» та ін.), яку тогочасна літературна критика трактувала як бліду тінь «книги Болю».

Стосовно цього можуть бути різні міркування, утім велику увагу привертає до себе журналістська політична діяльність О. Турянського, яку він розгорнув, перебуваючи на італійському острові Ельбі як інтернований офіцер австрійської армії. У прогресивних німецьких, італійських, англійських газетах та часописах перших декад XX сторіччя, зокрема «Hilfe», «Frankfurter Zeitung», «Hamburger Fremdenblatt», «Corriere della Sera», «Tribuna», «Avanti», «Tempo», «Manchester Guardian», О. Турянський відстоював українську справу, її державотворчий наратив. Власне, цей аспект діяльності кореспондента віденського часопису «Ukrainische Rundschau» досі недооцінений. Його науково-публіцистична та літературна спадщина посідає досить-та-

2 Дзись, Т. (2013), Літературний контекст у проекції типології та сприймання (Йозеф Рот, Осип Турянський, Іван Франко), Наукові записки Тернопільського начіонального педагогічного університету імені Володимира Гнатюка. Серія: Літературознавство. № 37. С. 294-304.

3 Мафтин, Н. (2011), Поетика експресіонізму в романі Осипа Турянського «Поза межами болю» та повісті Леоніда Андреєва «Червоний сміх», Слово $і$ Час, Київ, 2011. № 10, С. 24-32.

4 Моклиця, Марія (2017), Алегоричний код літератури, або Реабілітація алегорії триває: монограф., Київ, Кондор Видавництво, 292 с.

5 Нестелєєв, М. (2012), Поза межами й у межах: Осип Турянський і його найвідоміший твір, Дивослово, Київ, № 11, С. 50-56.

6 Парандовский, Я. (1990), Алхимия слова. Петрарка. Король жизни, Москва, Изд-во «Правда», C. 30 .

7 Див.: Печарський, А. (2003), Поетика творчості Осипа Турянського: монограф, Львів: Вид. центр ЛНУ ім. І. Франка, 2003, 202 с. 
ки виняткове місце серед багатьох тогочасних видатних українських діячів та ідеологів, зокрема Д. Донцова, В. Липинського, Ю. Липи, Д. Віконської та ін.

Узагалі-то український державотворчий наратив О. Турянського бачиться у глибині застиглого трепету етнопсихології. У долю цього незаперечного факту вплітається його власна концепція так званого «українського дводушшя», суть якої полягає в тому, що у внутрішніх порухах серця нашої нації живе дві душі: героя та раба. Відтак О. Турянський вважав основною доленосною причиною бездержавності українського народу його надмірний індивідуалізм, що виражається у непідпорядкуванні колективним інтересам і ненависті до влади взагалі, навіть до своєї. «У найбільшій частині українців, - на думку О. Турянського, - живе дві душі, душа героя та душа невільника. Геройська душа унасліджена від українських прапредків, котрі доконали чуда, гідного титанів: здобули наймогутнішу матеріальну підставу життя, найбільше плодючу медом і молоком текучу землю в Європі. Але славний український чорнозем став прокляттям для українських потомків. (Цією думкою схиляється до геопсихологічної концепції В. Липинського, що «причиною нашої бездержавності $\epsilon$ найбільше родюча земля в Європі і добре підсоння ${ }^{8} .-$ А. П.) <..> Він ослабив первісну енергію народу, розніжив його дух, який вживаючи вислову Цезаря «effeminatus est». Таким чином, постала друга, рабська душа, яка спричиниласа упадок великої Київської держави і зробила українців віковими рабами чужих народів, вихованих на багнах і пісках» ${ }^{9},-$ писав О. Турянський у статті «Рецензент і критик».

Свідомість О. Турянського як журналіста бунтує, розривається в баченні нашої історичної національної трагедії. Але, потрапляючи в зачароване коло власної підсвідомої сублімативної сфери душі, він як письменник не знаходить адекватного вираження своїм раціонально вмотивованим ціннісним міркуванням. Власне, з цих причин і ліричний роман «Поза межами болю», написаний про події Першої світової війни, позбавлений героїчно-вольового пафосу та відчуття бойового войовничого духу. На такі моменти звернув увагу Д. Донцов, пишучи, що війна у творі О. Турянського зображена крізь призму українця, якому «гранати не дають орати свою скибу.... ${ }^{10}$

Митець - раб свого народження, і це протиріччя його душі й розуму надає особливого етнопсихологічного статусу образам-символам у «книзі Болю».

Як зауважував Д. Донцов, українцям мало імпонувала «краса вічного руху, поезія здобувця, твердих м'язів і твердої волі <..> знали лише красу «гуманності», похилених у журбі чол і нарікання без кінця. Діяльність і рух - це було для Гегеля «вищий ідеал житя», для наших філософів - спокій і щастя в спокою. Непорушність, тиха погідність...» $\rangle^{11}$ Тому не випадково авторова пасивність у «Поза межами болю» О. Турянського спроектована здебільшого у малі прояви життя, тобто в порухи розвиненого сімейного почуття, любові до жінки.

Для тогочасної літературної преси така орієнтація митця на тлі воєнних подій, де війна дивиться не очима зброї, барикад чи військових маневрів, а внутрішньою

\footnotetext{
8 Липинський, В. (1927), Листи до Братів-Хліборобів. Про ідею і організаџію украйнського монархізму. Писані 1919-1926, Відень: Buchdruckerei Carl Herrmann, С. 422.

9 Турянський, О. (1927), Рецензент і критик, Літературні вісті, Ч. 3-4, С. 8.

10 Донцов, Д. (1966), Націоналізм, Лондон: Вид-во «УВС», С. 54

${ }^{11}$ Там само. С. 176.
} 
драмою людської душі, промовляючи не відлунням пострілів, а осколками болю, стала загадкою, феноменом творчого процесу. А втім, Ю. Липа в роботі «Призначення України» наче кидає просвіток на невияснені місця авторових душевних порухів, додаючи, що «власне українці мають вроджені здібності тривало репрезентувати і висловлювати свою асоціацію < ..> часто родинного характеру, і лише там можуть дати максимум енергії і витривалої праці та продуктивності» ${ }^{12}$.

Можна погодитися із припущенням, що пасивність авторової вдачі в екстремальній життєвій ситуації, описаній у «Поза межами болю» О. Турянського, 3 психологічної точки зору давала шанс вижити, бо суворі природні умови, обставини не давали йому змоги активізувати свою діяльність. Тож віра, оптимізм, що сприяють успішному виживанню, могли підтримуватися тільки у сфері пасивної психічної надбудови характеру людини. Проте пасивність головного героя, ідеалізація жіночого, сімейного образу пізніше зіграють негативну роль, приведуть автора до відчуженості і депресивного стану, що проявляється в його передмові до твору.

Таке увнутрішнення в формі ізоляції від суспільного життя хоча має універсальний екзистенційний характер, проте 3 нього випливає своєрідний «український егоцентризм», орієнтований на підпорядкування всім інтересам «Я». У доповіді «Українська духовність в її культурно-історичних виявах» на педагогічному конгресі у Львові 1935 року Я. Ярема наголошував: «Ізоляціонізм жив у національному ідеалі втечі від світу, як найдавніший ідеал християнства, що гармонізувало з утечею в містику чи в фантастичний світ ілюзій...»» ${ }^{13}$ (при тім зауважував, що І. Вишенський втік у монастир, Г. Сковорода усамітнювався серед природи, а М. Гоголь емігрував за кордон - А. П.). Намагаючись позбутися нестерпної дійсності, ми втікаємо від неї на самоту, чи то у світ власний - внутрішній, або їі не зауважуємо, або ідеалізуємо. У всіх тих випадках займаємо супроти неї пасивну поставу <..> між тими двома противенствами постійно хиталося українське життя» ${ }^{14}$. Сильна акцентація на сімейному вогнищі, а також мотиви відчуженості, що проявляється в ліричному романі «Поза межами болю» О. Турянського, здебільшого виявляють індивідуальні риси людини, які ведуть до браку згуртованості, дисципліни й творять не цивілізацію із стійкими державними структурами, а культуру. Ця підсвідома авторова психологічна установка суперечить його раціоналізації, а відтак теоретичним міркуванням щодо проблем української бездержавності. Адже як журналіст він бачив їх насамперед у надмірному прояві нашого індивідуалізму, що характерний, за юнгівським поділом, для інтровертного типу людини. У своїй «Трагедії українського психічного дуалізму» О. Турянський писав про «занепад спільного расового почуття» ${ }^{15}$ нашого народу: «Самолюбство й індивідуалізм - це споконвіку загальнолюдські хиби <.. > a під тим оглядом ці хиби, що розвалили українську державну спільноту, запустили в українських потомках куди глибше коріння, ніж у інших народах» ${ }^{16}$. О. Турянський, виходячи з цієї платформи аналізу української етнопсихології, у своїй публіцистиці

\footnotetext{
12 Липа, Ю. (1938), Призначення України, Львів: «Хортиця», С. 217.

13 Ярема, Я. (1938), Українська духовність в її кульурно-історичних виявах, Периий украӥнський педагогічний контрес 1935 р., Львів: Рідна школа, С. 47.

14 Там само, С. 59.

15 Турянський, О. (1928), Трагедія українського психічного дуалізму. Спроба нового освітлення «Слово о полку Ігоря», Діло. 26 липня. С. 2.

${ }^{16}$ Там само.
} 
виступав, зокрема, як і розважливий, політичний стратег. Так, він передбачив у ті часи розвал Радянського Союзу, вмотивовуючи це тим, що його «анархічна сутність вдачі $<\ldots>>$ затратила в собі почуття позитивної вартості держави. $<\ldots>$ Це відомий російський «нігілізм». <..> А відтак усі поневолені народи будуть мати нагоду й силу збудувати собі окремі національні держави»»17. Наведена думка О. Турянського щодо цієї проблематики сягає тих етнопсихологічних висот інтелекту людини, що могли б вибороти йому поважне місце серед тогочасних політичних аналітиків.

Проте, у можливості створення нашого національно-державного життя О. Турянський убачав деяку складність, тому що «на противагу до російського анархізму, який пасивністю російських мас знаменито придається до державного будування, стоїть український анархічний індивідуалізм, що признає державу в теорії, однак не вміє її збудувати або руйнує у практиці»» ${ }^{18}$.

Такий анархічний характер нашої вдачі проявлявся ще в державних структурах, законодавстві Київської Русі. Підтвердженням чого може служити і такий факт, - за свідченням М. Грушевського, - що «кожної хвилини міг дружинник князя покинути й перейти до іншого, хоч би й до ворога, не підпадаючи ніякій карі. Це був кардинальний принцип староруського (українського - А. П) устрою»19.

Складному, парадоксальному феномену нашого історичного державобудування можна протиставити інший - римський: місто лукулових оргій, гладіаторів і рабів. Створена римлянами імперія проіснувала на землі найдовше. Ї̈̈ грандіозні успіхи i велич викликали захоплення й заздрість багатьох політиків. У сиву давнину старі мудреці говорили, що в неї є інша, потаємна назва, яку можна прочитати по-східному - справа наліво. I тоді слово Roma (Рим) звучатиме як Amor (Любов). Така гра слів містила глибокий підтекст, що якоюсь мірою виражав суть таємниці могутнього державного устрою Риму. Це велика любов до твердого закону, порядку, громадського обов'язку і дисципліни. Парадоксальність так званого «українського дуалізму», що була висвітлена в журналістській творчості О. Турянського, зокрема в «Двох анархізмах», «Трагедії українського психічного дуалізму», співзвучна із деякими цінними зауваженнями таких етнопсихологів: П. Феденка, В. Яніва, Д. Віконської та ін. Це стосується саме нашої історичної владоненависності й владолюбства як засобу самовияву амбітних одиниць, погорди до ощадливості й грошей - символу комерційних відносин між людьми. У романі «Поза межами болю» О. Турянського такий життєвий гедонізм, що веде до примітивного виживання в тяжких умовах, простежуємо в образі Добровського. Його слова: «Товариші! Тепер ми вже не маємо грошей і також не потребуємо грошей. Тепер ми стали справжніми людьми» ${ }^{20}$, наче наслідували дії зголоднілого, божевільно злютованого Саба, який, кусаючи паперові гроші, кидав усім високопоставленим чиновникам: «Це ви - символ оцього хліва, що є сучасний державний і соціальний лад» ${ }^{21}$. А вислів Добровського: «Десять царів за один український пиріг» ${ }^{22}$ звучить у дусі перефразованої приповідки - на одного

17 Там само. С. 3.

${ }_{18}$ Турянський, О. (1921), Два анархізми, Соборна Украӥна, 23 листопада. С. 3.

19 Цит. за: Янів, В. (1993), Нариси до історії української етнопсихології. Мюнхен: Український Вільний університет, С. 51.

${ }^{20}$ Турянський, О. (1921), Поза межами болю. Відень-Чікаго: Вид-во компанії «У.-М.-НА», с. 98.

21 Там само, с. 95.

22 Там само, с. 83. 
українця три гетьмани. Певні твердження письменника грунтуються на трагічній історії нашого доленосного минулого й відповідної етнопсихології, бо постійне перебування України під гнітом інших держав виробило в підсвідомості народу ненависть до влади взагалі і своєї зокрема. Таким чином, зникає розуміння найважливіших державних форм організації влади у країні.

Найоригінальнішим сюжетом, що порушує цю проблему в творчості О. Турянського, є оповідання «Боротьба за великість», де змальовано Стаха Шалапуту - образ типового пересічного українця, людини, не здатної до сублімації інстинктів нижчих почутів у вищі соціальні сфери. Герой на докір священика щодо своєї патріотичності відповідає: «Мені ані в думці жити для такої України, що все витягає руку: дай та дай та дай! А що та Україна дасть мені?!»23. У світовідчутті, плеканні національних почуттів персонажа проходить конкретизація символу, і в такому випадку найвищою ціллю в житті стає власний добробут і збагачення, що приводить до дегенерації будь-які «соціальні інстинкти» людини.

Індивідуалізм розвинувся в нас у парі з непідпорядкуванням, а отже, й з нестерпним почуттям, нехіттю до закону, організованості. Саме через брак дисципліни Д. Віконська пояснювала вияв «рабської психіки» українців, для яких «воля означає <.. > визволення «від чогось», від чужого панування <.. > від свого авторитету, якого неохоче слухаємо. «Паліть універсали, топчіть декрети, проклинайте закони й канцелярський сказ - воля! - єдиний хай буде наказ!», - слова Тичини - є зразком поняття такої «волі» ${ }^{24}$, вважала Д. Віконська. Це результат надмірного невгамовного прояву українського індивідуалізму, який відіграє позитивну роль у розвитку культуротворчої сфери і одночасно негативну - щодо державобудівної, бо несе загрозу анархізму й пацифізму.

Цієї засадничої думки притримувався й О. Турянський. У його алегоричній повісті «Дума пралісу» звірі, розігруючи між собою комічну сцену міжнаціональних конфліктів поневолених народів періоду Першої світової війни, щиро дивувалися 3 психологічної поведінки українців, що, перебуваючи в неволі, з симпатією ставилися навіть до своїх історичних ворогів. Яскравим символічним прикладом $є$ гімн України «Згинуть наші вороженьки, як роса на сонці...»» ${ }^{25}$, де на несвідомому рівні у зменшувально-пестливій формі слова «вороженьки» проявляється любов поневоленого народу до своїх неприятелів. Певні настрої межують також із пасивною мрійливістю, вірою в автоматичність поступу бажань. Бо «роса на сонці» щезає сама собою. Це природний процес, до якого не потрібно докладати жодних зусиль. Схожа етнопсихологічна концепція мислення стосовно українського державотворчого наративу простежується і в пресовому дискурсі О. Турянського, зокрема в таких публікаціях: «Французько-польська приязнь», «Два анархізми», «Хто з нами, а хто проти нас?», «Моя розмова 3 др. Бенешом» (інтерв’ю з чеським міністром закордонних справ», «Рецензент і критик», «Трагедія українського психічного дуалізму» та ін.

\footnotetext{
${ }^{23}$ Турянський, О. (1926), Боротьба за великість. Київ-Львів-Рогатин: Вид-во «Журавлі», с. 14.

${ }^{24}$ Віконська, Д. (1956), За силу і перемогу, Визвольний Шлях, Кн. 8, с. 867.

${ }^{25}$ Див.: Турянський, О. (1922), Дума пралісу. Київ-Відень: Накладом українського вид-ва «Аполон», $239 \mathrm{c}$.
} 
Результати і перспективи подальших досліджень. Державотворчий наратив у пресовому дискурсі О. Турянського висвітлює проблему розмежування індивідуального чинника людської думки від національного. Допускаючи можливість винятків (бо не всі представники певного народу мають типові спільні риси, які $\epsilon$ характерними для нього 3 погляду етнопсихології), до уваги береться більшість, що $\epsilon$ вирішальною для образу нації. А тому, незважаючи на постійний теоретичний сумнів, усе ж вплив середовища на загал є сильнішим від індивідуального чинника людської психіки, й упродовж різних епохальних перемін зберігається якась постійна його «константа», про що свідчить цілий цикл повторюваних подій в історії окремих народів. Цю незмінність етнопсихологічних особливостей української нації, що впливає на результати державотворення, чітко висвітлив у своїй журналістській та літературній творчості О. Турянський. Отже, перспективи подальших досліджень цієї проблематики стають очевидними.

Висновок. Державотворчий наратив у пресовому дискурсі О. Турянського дає змогу збагнути етнопсихологічну проблематику українського народу, що проявляється в надмірному індивідуалізмі, домінуванні емоційно-вольових чинників над раціональними та рабській психології, яка забезпечує певну неоднорідність у способах мислення, бажань та конформістських дій.

\section{СПИСОК ЛІТЕРАТУРИ}

1. Віконська, Д. (1956), «За силу і перемогу», Визвольний Шлях, 1956, Кн. 8. С. $836-$ 877.

2. Дзись, Т. (2013), «Літературний контекст у проекції типології та сприймання (Йозеф Рот, Осип Турянський, Іван Франко)», Наукові записки Тернопільського наиіонального педагогічного університету імені Володимира Гнатюка, Серія: Літературознавство, № 37. С. 294-304.

3. Донцов, Д. (1966), Наиіоналізм. Лондон, Вид-во «УВС», 363 с.

4. Липа, Ю. (1938), Призначення України, Львів, «Хортиця», 305 с.

5. Липинський, В. (1927), Листи до Братів-Хліборобів. Про ідею і організацію українського монархізму. Писані 1919-1926, Відень, Buchdruckerei Carl Herrmann, 580 c.

6. Мафтин, Н. (2011), «Поетика експресіонізму в романі Осипа Турянського «Поза межами болю» та повісті Леоніда Андреєва «Червоний сміх», Слово $i$ Час, Київ, 2011, № 10, c. 24-32.

7. Моклиця, М. (2017), Алегоричний код літератури, або Реабілітація алегорії триває: монограф., Київ, КондорВидавництво, 292 с.

8. Нестелєєв, М. (2012), «Поза межами й у межах: Осип Турянський і його найвідоміший твір», Дивослово, Київ, № 11, с. 50-56.

9. Парандовский, Я. (1990), Алхимия слова. Петрарка. Король жизни, Москва, Правда, 656 с.

10. Печарський, А. (2003), Поетика творчості Осипа Турянського, монограф., Львів, Вид. центр ЛНУ ім. І. Франка, 202 с.

11. Прохасько, Т. (2019), Периа світова війна в украӥнській класичній літератуpi: О. Турянський. Лекція. URL: https://culturalproject.org/lectures/55ad008787cb$94 \mathrm{c} 0378 \mathrm{~b} 47 \mathrm{~d} 4$

12. Турянський, О. (1926), Боротьба за великість, Київ-Львів-Рогатин, Журавлі, 77 с. 
13. Турянський, О. (1921), «Два анархізми», Соборна Украӥна, 23 листопада, с. 3-4.

14. Турянський, О. (1922), Дума пралісу, Київ-Відень: Накладом українського вид-ва «Аполон», 239 с.

15. Турянський, Осип (1921), Поза межами болю, Відень-Чікаго: Вид-во компанії «У.-М.-НА», 173 c.

16. Турянський, О. (1927), Рецензент і критик, Літературні вісті. Ч. 3-4, с. 6-10.

17. Турянський, О. (1928), «Трагедія українського психічного дуалізму. Спроба нового освітлення «Слово о полку Ігоря», Діло, 26 липня, с. 2-4.

18. Янів, В. (1993), Нариси до історії української етнопсихологї̈, Мюнхен: Український Вільний університет, 217 с.

19. Ярема, Я. (1938), «Українська духовність в її культурно-історичних виявах», Перший український педагогічний контрес 1935 р., Львів, Рідна школа, с. 16-88.

\section{REFERENCES}

1. Vikonska, D. (1956), «Za sylu i peremohu», Vyzvolnyi Shliakh, 1956, Kn. 8. S. 836-877.

2. Dzys, T. (2013), «Literaturnyi kontekst u proektsii typolohii ta spryimannia (Iozef Rot, Osyp Turianskyi, Ivan Franko)», Naukovi zapysky Ternopilskoho natsionalnoho pedahohichnoho universytetu imeni Volodymyra Hnatiuka. Seriia: Literaturoznavstvo, № 37, s. 294-304.

3. Dontsov, D. (1966), Natsionalizm. London, Vyd-vo «UVS», 363 s.

4. Lypa, Y. (1938), Pryznachennia Ukrainy, Lviv: «Khortytsia», 305 s.

5. Lypynskyi, V. (1927), Lysty do Brativ-Khliborobiv. Pro ideiu i orhanizatsiiu ukrainskoho monarkhizmu. Pysani 1919-1926, Viden, Buchdruckerei Carl Herrmann, 580 s.

6. Maftyn, N. (2011), «Poetyka ekspresionizmu v romani Osypa Turianskoho «Poza mezhamy boliu» ta povisti Leonida Andreieva «Chervonyi smikh», Slovo i Chas, Kyiv, 2011, № 10, s. 24-32.

7. Moklytsia, M. (2017), Alehorychnyi kod literatury, abo Reabilitatsiia alehorii tryvaie: monohraf., Kyiv, KondorVydavnytstvo, 292 s.

8. Nestelieiev, M. (2012), «Poza mezhamy y u mezhakh: Osyp Turianskyi i yoho naividomishyi tvir», Dyvoslovo, Kyiv, № 11, s. 50-56.

9. Parandovskyi, Ya. (1990), Alkhymyia slova. Petrarka. Korol zhyzny, Moskva, Pravda, $656 \mathrm{~s}$.

10. Pecharskyi, A. (2003), Poetyka tvorchosti Osypa Turianskoho, monohraf., Lviv: Vyd. tsentr LNU im. I. Franka, 202 s.

11. Prokhasko, T.(2019), Persha svitova viina vukrainskii klasychnii literaturi: O. Turianskyi. Lektsiia. URL: https://culturalproject.org/lectures/55ad008787cb94c0378b47d4

12. Turianskyi, O. (1926), Borotba za velykist, Kyiv-Lviv-Rohatyn, Vyd-vo «Zhuravli», $77 \mathrm{~s}$.

13. Turianskyi, O. (1921), Dva anarkhizmy, Soborna Ukraina, 23 lystopada, s. 3-4.

14. Turianskyi, O. (1922), Duma pralisu, Kyiv-Viden: Nakladom ukrainskoho vyd-va «Apolon», $239 \mathrm{~s}$.

15. Turianskyi, O. (1921), Poza mezhamy boliu, Viden-Chikago: Vyd-vo kompanii «U. M. NA», $173 \mathrm{~s}$.

16. Turianskyi, O. (1927), «Retsenzent i krytyk», Literaturni visti, Ch. 3-4, s. 6-10. 
17. Turianskyi, O. (1928), «Trahediia ukrainskoho psykhichnoho dualizmu. Sproba novoho osvitlennia «Slovo o polku Ihoria», Dilo, 26 lypnia, s. 2-4.

18. Yaniv, V. (1993), Narysy do istorii ukrainskoi etnopsykholohii, Miunkhen: Ukrainskyi Vilnyi universytet, $217 \mathrm{~s}$.

19. Yarema, Ya. (1938), «Ukrainska dukhovnist v yii kulurno-istorychnykh vyiavakh», Pershyi ukrainskyi pedahohichnyi kongres 1935 r., Lviv, Ridna shkola, s. 16-88.

\title{
STATE-SHAPING NARRATIVE \\ IN THE PRESS DISCOURSE OF OSYP TURIANSKYI
}

\author{
Andriy Pecharskyi \\ Ivan Franko National University of Lviv, \\ 1 Universytetska Str., 79000, Lviv, Ukraine \\ e-mail:pecharskyy@ukr.net \\ https://orcid.org/0000-0003-4154-8956
}

The article is devoted to the typological characteristic of the journalistic and literary heritage of O. Turyanskyi through the prism of the Ukrainian state-shaping narrative. The main attention is paid to the ethno-psychological problems of the Ukrainian people with regard to their tragic fateful development of the nation-state. In this aspect, O. Turyanskyi adhered to his own conception of the so-called "Ukrainian duplicity», the essence of which is that there are two souls in the inner disturbances of the heart of our people: the hero and the slave. In his journalism, in particular in 'The Two Anarchisms' and 'The Tragedy of Ukrainian Mental Dualism', O. Turyanskyi addressed the problem of the quantitative correlation of the mind, feelings and will of the Ukrainian people. He emphasized that at the heart of our nation, the main driving forces of activity are not ratio but feelings and emotions. Therefore, the overriding individualism, expressed in disobedience to collective interests, was considered the main fatal reason for the statelessness of the Ukrainian people. Hence the hatred of the authorities in general - even their own - O. Turyanskyi also adhered to the geopsychological concept of V. Lypynskyi and the principle of voluntarism of D. Dontsov regarding the ethnopsychological problems of the Ukrainian state formation.

Key words: ethno-psychological aspect, state-building narrative, «Ukrainian duplicity», excessive individualism, egocentrism. 